\title{
Pertumbuhan rumput laut (Eucheuma cottonii) dengan berat bibit awal berbeda di Pantai Pandawa, Bali
}

\author{
The grow of seaweeds (Eucheuma cottonii) in different initial weight at \\ Pandawa Beach, Bali
}

\author{
Ni Pande Putu Suji Dian Antari ${ }^{1}$, Ni Luh Watiniasih ${ }^{2, *}$, Ayu Putu Wiweka Krisna Dewi ${ }^{1}$ \\ 1) Program Studi Manajemen Sumberdaya Perairan, Fakults Kelautan dan Perikanan, \\ Universitas Udayana, Badung, Bali-Indonesia \\ 2) Program Studi Biologi, Fakultas Matematika dan Ilmu Pengetahuan Alam, \\ Universitas Udayana, Badung, Bali-Indonesia \\ *Email: watiniasih@gmail.com
}

Diterima 14 Juli $2021 \quad$ Disetujui 13 Agustus 2021

\section{INTISARI}

Rumput laut Eucheuma cottonii merupakan salah satu jenis rumput laut yang sering dibudidayakan oleh masyarakat adalah Eucheuma cottonii. Berat awal bibit yang ditanam dapat berpengaruh terhadap pertumbuhan rumput laut. Hasil penelitian menunjukkan berat bibit rumput laut yang baik digunakan berkisar antara 50-150 gr, namun belum ada penelitian secara detail pada E. cottonii yang ditaman dengan metode rakit apung. Penelitian ini bertujuan untuk mengetahui berat bibit awal rumput laut yang baik untuk pertumbuhan E. cottonii pada metode rakit apung dengan bibit diletakkan di dalam kantong. Penelitian ini terdiri dari 3 perlakuan yaitu perlakuan A dengan berat bibit 50 gr, perlakuan B dengan berat bibit 100 gr, dan perlakuan $\mathrm{C}$ dengan berat bibit 150 gr. Penelitian ini dilaksanakan di Pantai Pandawa, Bali, dari bulan Maret-April 2021, dimana data diambil sekali dalam seminggu selama 7 minggu. Hasil penelitian menunjukkan bahwa pertumbuhan rumput laut meningkat setiap minggunya dan berbeda antar perlakuan. Berat akhir rumput laut pada perlakuan A adalah 558,83 gr, perlakuan B sebesar 552,167 gr, dan perlakuan C sebesar 529,67 gr. Pertumbuhan rumput laut pada perlakuan A lebih tinggi dibandingkan perlakuan B dan C. Rata-rata Specific Growth Rate (SGR) pada perlakuan A adalah 4,92 \%, perlakuan B sebesar 3,48 \%, dan perlakuan $\mathrm{C}$ sebesar 2,57 \%. Hasil terbaik dari bibit yang digunakan ditemukan pada bibit dengan berat awal 50g, dibandingkan dengan berat bibit yang lain $(\mathrm{p}<0,002)$.

Kata kunci: Pantai Pandawa, Bali, rumput laut, Eucheuma cottonii, berat awal, SGR

\begin{abstract}
Seaweed is a low-level plant, does not have exact roots, stems, and leaves, and the plant part is called the thallus. One species that is often cultivated by the seaweed farmers in Bali is Eucheuma cottonii. The initial weight of the seeds planted can affect the growth of seaweed. The results of the study found that good seaweed seeds used ranged from 50-150 g, but has never been studied in detail on E. cottonii using floating raft method. This study aims to determine the initial weight of seaweed seeds that are good for growth using the floating raft method where the seeds are placed in a bag. This study consisted of 3 treatments, namely treatment A with a seed weight of $50 \mathrm{~g}$, treatment B with a seed weight of $100 \mathrm{~g}$, and treatment $\mathrm{C}$ with a seed weight of $150 \mathrm{~g}$. This research was conducted at Pandawa Beach, Bali, from March-April 2021, which data was collected once a week for 7 weeks. The results showed that the growth of seaweed increased every
\end{abstract}


week and different between treatments. The final weight of seaweed in treatment A was $558.83 \mathrm{~g}$, treatment $\mathrm{B}$ was $552.167 \mathrm{~g}$, and treatment $\mathrm{C}$ was $529.67 \mathrm{~g}$. Seaweed growth in treatment A was higher than treatment B and C. The average Specific Growth Rate (SGR) in treatment A was $4.92 \%$, treatment B was 3.48\%, and treatment $\mathrm{C}$ was $2.57 \%$. The best results from the seeds used were found in seedlings with an initial weight of 50g, compared to the weight of other seeds $(\mathrm{P}<0.002)$.

\section{Keywords: Pandawa Beach, Bali, rumput laut, Eucheuma cottonii, initial weight, SGR}

\section{PENDAHULUAN}

Eucheuma cottonii merupakan rumput laut yang mempunyai nilai ekonomis tinggi dimana sebagai penghasil karagenan (Damayanti et al., 2019). Karagenan banyak digunakan di dalam pembuatan makanan yang biasanya digunakan untuk meningkatkan tekstur keju, puding atau makanan penutup, pembuatan roti, sosis, dan hamburger rendah lemak sebagai pengikat dan stabilisator. Karagenan juga digunakan dalam preparasi pasta gigi, busa pemadam kebakaran, sampo gel dan krim kosmetik. Karegenan terutama digunakan sebagai agen agen peningkat viskositas pada formulasi farmasetik seperti suspensi, emulsi, gel, cream, lotion, tetes mata, suppositoria, tabletdan kapsul (Prihastuti dan Abdassah, 2019)

Pada pertumbuhan rumput laut diperlukan upaya dalam mencukupi kebutuhan dalam meningkatkan budidaya yang intensif dimana terdapat faktor internal yang mempengaruhi pertumbuhan rumput laut yaitu spesies, bagian thallus dan umur, sedangkan faktor eksternalnya yaitu lingkungan, jarak tanaman, berat bibit awal, teknik penanaman dan metode budidaya (Fikri et al., 2015). Keberhasilan suatu budidaya rumput laut dapat ditentukan oleh metode budidaya yang tepat, kualitas lingkungan yang baik, serta penggunaan berat bibit awal yang akan digunakan dalam budidaya rumput laut. Bibit rumput laut didapatkan dengan melakukan stek pada tumbuhan rumput laut yang masih muda, terhindar dari penyakit, dan masih segar, tidak cacat serta diambil dari tanaman yang tumbuh secara alami atau hasil budidaya (Ariyanto, 2005). Menurut Sudjiharno (2001), bibit yang dikatakan baik untuk pertumbuhan berkisaran antara 50-100 gr. Salah satu pantai di Bali yang dijadikan tempat budidaya rumput laut adalah Pantai Pandawa.

Pantai Pandawa terletak di Desa Kutuh, Kabupaten Badung, Bali. Pantai Pandawa memiliki potensi lahan yang cocok untuk dijadikan sebagai tempat budidaya rumput laut yang cukup menjanjikan bagi masyarakat setempat. Namun, semakin berkembangnya zaman, mengakibatkan kebanyakan pembudidaya rumput laut beralih profesi menjadi pekerja wisata bahari (Dewi \& Saraswati, 2016; Medinawati, 2017). Banyaknya kendala yang ditemukan saat membudidayakan rumput laut menjadi pertimbangan bagi para pembudidaya untuk tidak melakukan kegiatan budidaya, seperti halnya rumput laut rentan terhadap serangan predator dan penyakit, sehingga budidaya rumput laut memerlukan pagar untuk dapat melindungi pertumbuhan thallus rumput laut (Dewi \& Ekawaty, 2019). Salah satu alat yang dapat digunakan sebagai pelindung dari pertumbuhan rumput laut yaitu penggunaan kantong rumput laut mampu mencegah masuknya sampah maupun hewan pemangsa (Mako et al, 2018; Dewi \& Suryaningtyas, 2020), serta kurangnya pemahaman masyarakat tentang kesesuaian berat bibit awal yang digunakandalam budidaya rumput laut. Pembudidaya biasanya menggunakan perkiraan saja sehingga tidak mengetahui pasti berapa berat bibit yang baik untuk meningkatkan hasil budidaya. Hal tersebut dapat menyebabkan produksi rumput laut menjadi menurun (Hamid, 2009). Oleh karena itu, penelitian ini penting dilakukan untuk mengetahui berat bibit awal yang sesuai untuk dapat dibudidayakan kembali di sekitaran Pantai Pandawa dengan menggunakan metode penanaman rakit apung modifikasi kantong untuk melindungi pertumbuhan rumput laut sehingga 
dapat menghasilkan laju pertumbuhan rumput laut yang baik dan berkualitas.

\section{MATERI DAN METODE}

Metode yang digunakan dalam penelitian ini yaitu metode ekperimental RAK yang menggunakan 3 perlakuan yaitu pada perlakuan A (berat awal $50 \mathrm{gr}$ ), perlakuan B (berat awal 100 gr), dan perlakuan C (berat awal 150 gr). Masingmasing perlakuan dilakukan pengulangan sebanyak 4 kali pengulangan. Pengambilan data dilakukan dalam selang waktu 1 minggu sekali selama 7 minggu penelitian.

\section{Tempat dan waktu penelitian}

Penelitian ini dilaksanakan di perairan Pantai Pandawa Bali selama 2 bulan, dimulai dari Bulan Maret sampai dengan April 2021. Lokasi penelitian Pantai Pandawa dapat dilihat pada Gambar 1.

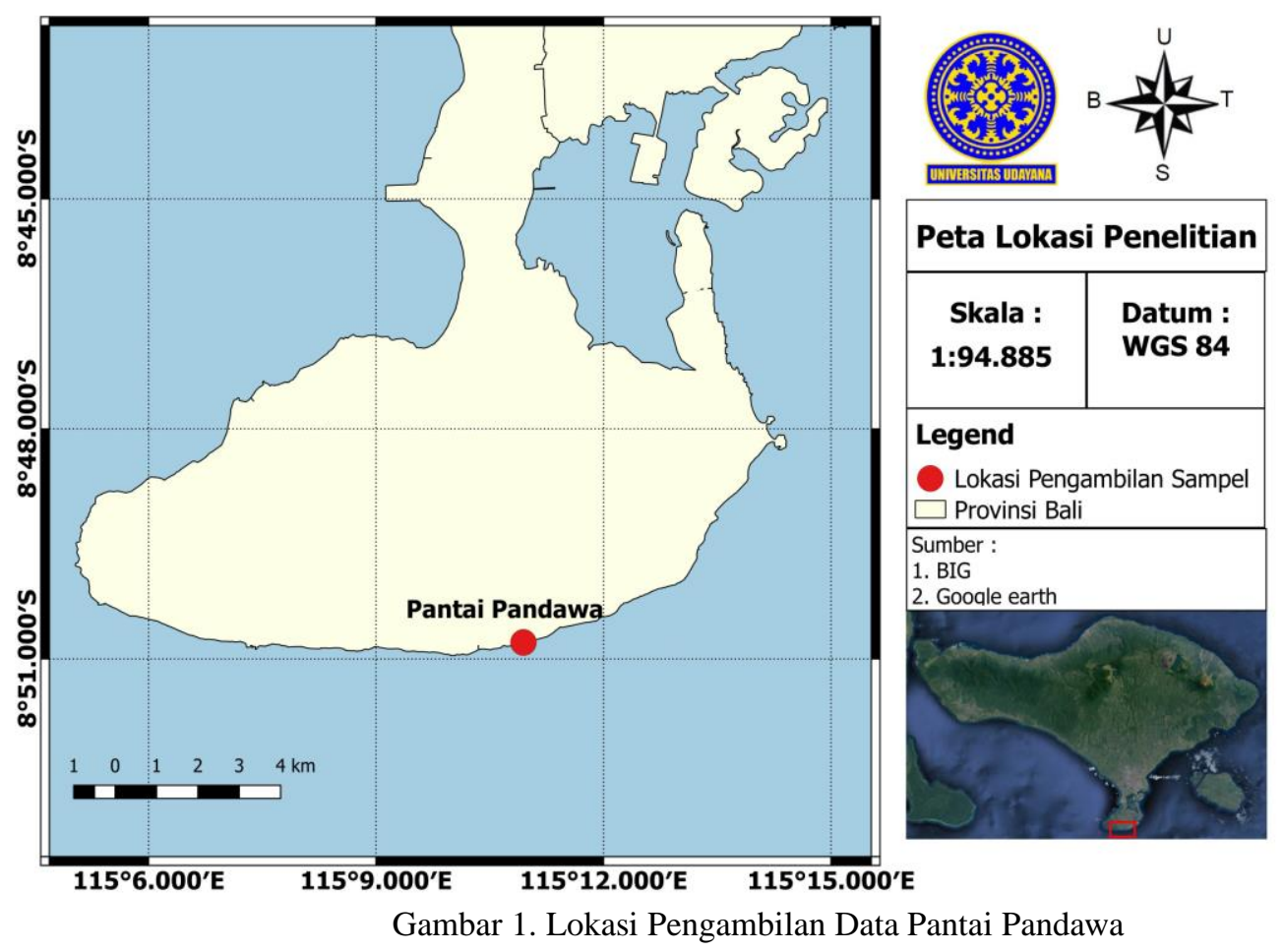

\section{Bahan dan alat penelitian}

Alat-alat yang digunakan pada penelitian ini yaitu timbangan digital, bambu, jaring, tali ris, besi, botol air mineral, batu, tali rafia, plastic es, gunting, pH meter, refraktometer. Sedangkan bahan yang digunakan pada penelitian ini yaitu rumput laut Eucheuma cottonii.

\section{Prosedur Penelitian}

Bibit rumput laut yang digunakan dalam penelitian ini, yaitu bibit rumput laut Euhceuma cottonii yang berasal dari hasil budidaya di Pantai Geger. Bibit kemudian ditimbang dengan perbedaan perlakuan berat bibit awal yakni $50 \mathrm{~g}$, $100 \mathrm{~g}$, dan $150 \mathrm{~g}$.
Pembuatan metode rakit yang digunakan berukuran 1 x 1 meter, terbuat dari bahan bambu. Untuk membuat satu buah rakit memerlukan 4 buah bambu besar ukuran panjang 1,5 meter, untuk membentuk persegi empat (rangka utama), dan 2 buah bambu kecil berukuran panjang $1 \mathrm{~m}$, sebagai tempat diikatnya tali ris rumput laut terletak pada bagian bawah bambu besar. Sesuai dengan metode, pada kedua sisi rakit sepanjang 1 $\mathrm{m}$ diikatkan tali ris sebanyak 4 tali ris, dengan jarak antara tali ris yang satu dengan yang lain 20 $\mathrm{cm}$, kemudian pada setiap tali ris diikatkan tali anak sebanyak 5 titik sehingga jumlah total nya 20 titik. Pada tali anak itu diikatkan bibit rumput laut dengan ikatan simpul hidup yang bertujuan agar mempermudah dalam monitoring dan 
evaluasi pertumbuhan rumput laut serta pada rakit diberikan kantong agar rumput laut terhindar dari serangan predator.

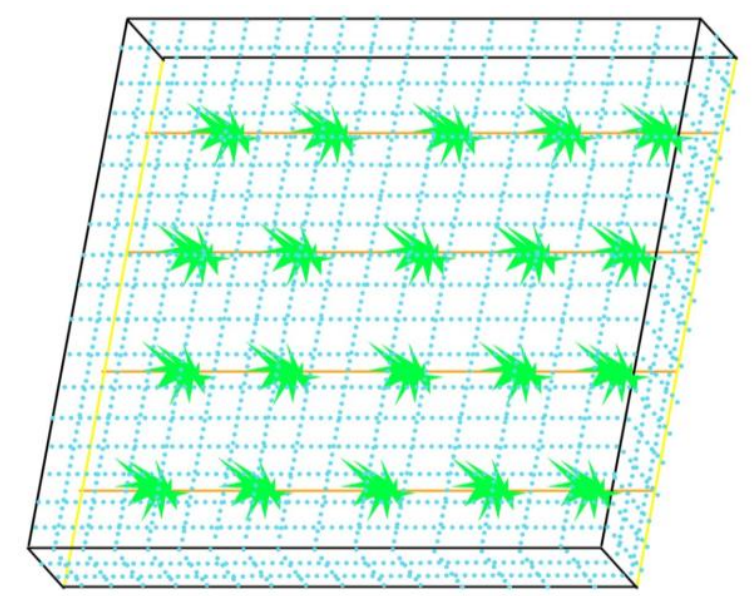

Gambar 2. Disain Penanaman Rumput Laut

Keterangan:

$$
\begin{aligned}
& =\text { tali ris } \\
& =\text { bambu } \\
& =\text { rumput laut } \\
& =\text { kantong/jaring rumput laut }
\end{aligned}
$$

Pengamatan pertumbuhan rumput laut bertujuan untuk mengetahui pertumbuhan berat rumput laut dengan melakukan penimbangan bobot rumput laut. Selain itu, untuk membersihkan kotoran yang menempel pada rumput laut. Penimbangan dilakukan dengan pengambilan 2 titik sampel dalam satu tali ris secara acak, sehingga dalam 1 rakit (kantong) terdapat 8 sampel yang digunakan pada masingmasing perlakukan. Penimbangan dilakukan dengan cara membuka kantong kemudian menimbang berat bibit rumput laut lalu mengikat kembali kantong. Terdapat 3 titik pengamatan sesuai perlakukan, masing-masing perlakuan dilakukan pengulangan sebanyak 4 kali. Secara keseluruhan terdapat 60 sampel dari 3 rakit apung modifikasi kantong yang digunakan.

Data penunjang diambil dengan beberapa pengukuran parameter kualitas perairan. Pengukuran kualitas air dilakukan di Laboratorium Perikanan Universitas, Udayana yang meliputi nitrat dan fosfat yang dilakukan 3 kali dalam jangka waktu 2 bulan penelitian.
Sedangkan, pengukuran kualitas perairan seperti DO (oksigen terlarut), salinitas, $\mathrm{pH}$, dan suhu dilakukan pengukuran 1 kali seminggu secara langsung di lapangan.

Hasil pertambahan bobot, kemudian dihitung dengan laju pertumbuhan perhari dengan menggunakan rumus sebagai berikut:

$$
S G R=\frac{\ln W t-\ln W o}{\mathrm{t}} \times 100 \%
$$

Keterangan:

SGR = Laju pertumbuhan bobot perhari (gram/hari \%)

$\mathrm{Wt}=$ Bobot rata-rata rumput laut pada akhir penelitian $(\mathrm{g})$

W0 = Bobot rata-rata rumput laut awal penelitian $(\mathrm{g})$

$\mathrm{t}=$ Lama pemeliharaan (hari) Anggadireja et al, (2008)

\section{Analisis Data}

Data SGR dianalisis menggunakan uji One Way Anova, dengan taraf signifikan 5\% dimana hasil dari analisisnya yakni kebenarannya sebesar 95\%. Uji statistik dibantu dengan menggunakan software SPSS PC. Var 25.0. Apabila hasil yang diperoleh pada uji Anova siginifikansi maka akan dilakukan uji lanjutan menggunakan Duncan's Multiple Range Test (DMRT) dengan taraf $5 \%$ (Damayanti et al., 2019)

\section{HASIL}

\section{Pertumbuhan Rumput Laut}

Pertumbuhan berat rumput laut meningkat setiap minggunya selama masa pemeliharaan. Pertumbuhan berat rumput laut Eucheuma cottonii yang dibudidayakan selama kurun waktu 7 minggu dengan berat bibit awal yang berbeda yaitu perlakuan A (berat awal 50 gr), perlakuan B (berat awal 100 gr), dan perlakuan C (berat awal 150 gr) menunjukkan hasil peningkatan pada setiap minggunya (Gambar 3).

Berat dari masing-masing pertumbuhan rumput laut ini sama-sama mengalami peningkatan dimana pada saat rumput laut dipanen pada minggu ke-7 perlakuan A memiliki berat rumput laut sebesar 558,83 gr, pada perlakuan B sebesar 552,17 gr, dan pada perlakuan C sebesar 529,67 gr. Hasil dari analisis ANOVA pada pertumbuhan 
berat rumput laut yaitu diperoleh nilai signifikasi sebesar $p<0,002$. Hal ini menunjukkan bahwa perlakuan berat bibit awal yang berbeda dengan metode rakit apung modifikasi kantong memberikan pengaruh beda nyata terhadap pertumbuhan berat rumput laut Eucheuma cottonii.

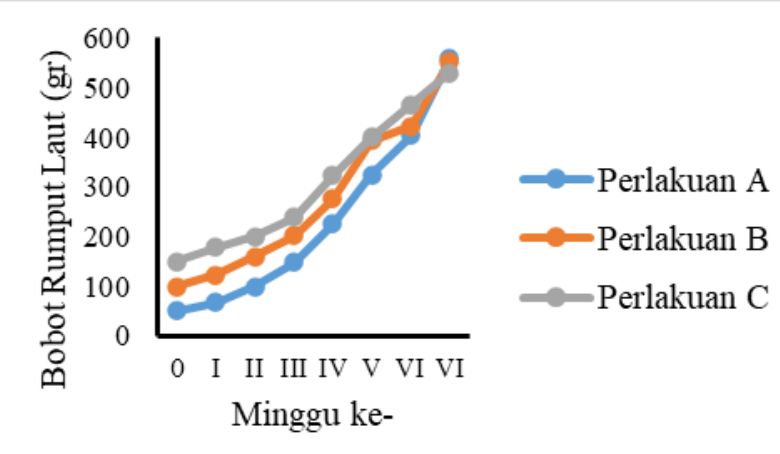

Gambar 3. Pertumbuhan rumput laut

\section{Laju Pertumbuhan Spesifik}

Hasil perhitungan nilai laju pertumbuhan spesifik pada pertumbuhan rumput laut dengan menggunakan kantong yakni pada perlakuan A sebesar 4,92\%, perlakuan B sebesar 3,48\%, dan perlakuan C sebesar 2,57\% (Gambar 4).

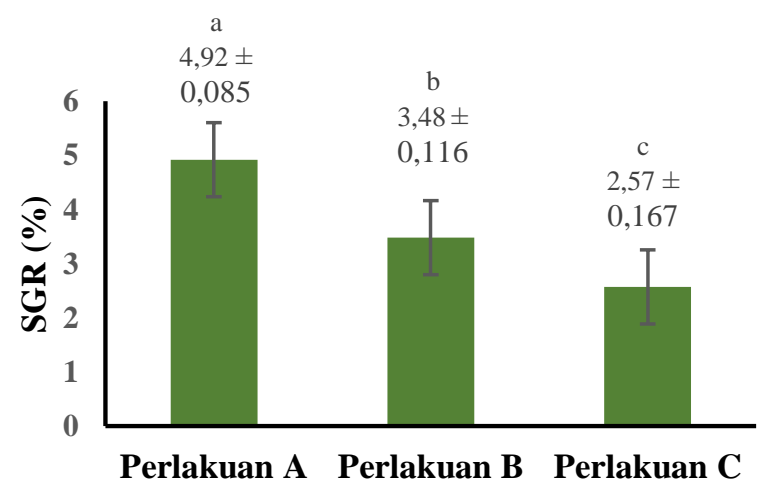

Gambar 4. Laju Pertumbuhan Rumput Laut Keterangan:

Huruf superscript yang berbeda pada gambar menunjukkan: tidak berbeda nyata (a), berbeda nyata (b), dan berbeda sangat nyata (c)

Laju pertumbuhan spesifik rumput laut perlakuan A $(50 \mathrm{~g})$ lebih cepat mengalami pertumbuhan dibandingkan perlakuan B (100 g) dan perlakuan $\mathrm{C}(150 \mathrm{~g})$ diduga disebabkan karena rumput laut dengan berat bibit $50 \mathrm{~g}$ lebih memiliki banyak ruang untuk tumbuh sehingga kebutuhan nutrisi terbagi secara merata dan kompetisinya dalam memperoleh nutrisi tidak terlalu ketat dibandingkan dengan rumput laut dengan berat bibit $100 \mathrm{~g}$ dan $150 \mathrm{~g}$.

Laju pertumbuhan spesifik dari rumput laut diperoleh nilai signifikasi sebesar $p<0,001$. Berdasarkan hasil dari analisis ANOVA maka dilanjutankan dengan uji Duncan dan mendapatkan hasil bahwa pada nilai laju pertumbuhan spesifik rumput laut memberikan pengaruh yang berbeda nyata atau signifikan terhadap nilai laju pertumbuhan spesifik rumput laut tiap perlakuannya.

\section{Parameter Kualitas air}

Parameter kualitas air yang diukur meliputi parameter fisika dan parameter kimia. Kisaran suhu perairan saat penelitian adalah 28,7 - 30,6 ${ }^{\circ} \mathrm{C}$, dengan nilai $\mathrm{pH}$ relatif rendah yaitu $6,81-7,64$ ppt, namun masih dalam rentan kelayakan dalam pertumbuhan rumput laut. Oksigen terlarut dalam perairan di

lokasi penelitian relatif tinggi yaitu 5,4-6,5 $\mathrm{mg} / \mathrm{l}$, dengan kisaran nilai salinitas 30-32 ppt. Hasil dari data kualitas air dapat dilihat pada Tabel 1.

Tabel 1. Hasil Pengukuran Kualitas Air

\begin{tabular}{c|ccccccc}
\hline \multicolumn{7}{c}{ Minggu ke- } \\
\hline & $\mathbf{1}$ & $\mathbf{2}$ & $\mathbf{3}$ & $\mathbf{4}$ & $\mathbf{5}$ & $\mathbf{6}$ & $\mathbf{7}$ \\
\hline Suhu & 29.3 & 28.7 & 29.2 & 30.5 & 30.6 & 29.5 & 31 \\
pH & 6.9 & 7.55 & 7.64 & 6.81 & 7.2 & 7 & 6.96 \\
DO & 6.2 & 5.9 & 5.4 & 6.1 & 5.85 & 6.5 & 5.8 \\
Salinitas & 30 & 31 & 30 & 31 & 32 & 32 & 32 \\
Nitrat & 0.1986 & - & - & 0.19 & - & - & 0.255 \\
Fospat & 0.06378 & - & - & 0.058 & - & - & 0.052 \\
\hline
\end{tabular}

\section{PEMBAHASAN}

\section{Pertumbuhan Rumput Laut}

Berdasarkan Gambar 3 pertumbuhan bobot rumput laut pada minggu ke-1 mengalami pertumbuhan yang relatif kecil dibandingkan pada minggu ke-2 hingga minggu ke-7. Hal ini dikarenakan pada minggu ke-1 rumput laut masih mengalami aklimatisasi atau penyesuaikan diri dengan keadaan lingkungan sekitar serta 
mengalami proses penyembuhan luka akibat potongan saat rumput laut akan dijadikan bibit. Pernyataan tersebut juga didukung oleh Riris et al. (2019) yang menyatakan bahwa pada 7 hari pertama pemeliharaan merupakan waktu untuk rumput laut beraklimatisasi. Adanya proses aklimatisasi pada thallus menyebabkan thallus yang tidak dapat beradaptasi dengan baik pada kondisi perairan yang baru mengalami perubahan warna menjadi putih pucat, rapuh dan bahkan patah pada bagian ujung thallus yang menyebabkan bobot thallus berkurang.

Pertumbuhan rumput laut pada minggu ke-2 sampai minggu ke-5 sudah mulai mengalami peningkatan. Hal ini merupakan suatu pertanda pertumbuhan rumput laut sudah melewati fase adaptasi dengan baik. Hal tersebut juga didukung oleh pernyataan Aldoni (2011) yang menyatakan bahwa peningkatan pertumbuhan rumput laut yang sangat baik dapat terjadi setelah melewati fase adaptasi dan dipengaruhi oleh kualitas lingkungan yang baik. Pertumbuhan rumput laut semakin cepat pada minggu ke-6 dan minggu ke7. Pertumbuhan berat bibit rumput laut pada penelitian ini masih mengalami peningkatan sampai minggu ke-7. Hal ini diduga bahwa rumput laut masih mengalami pertumbuhan cepat dan belum mencapai fase stasioner. Kasim \& Asnani (2012) menyatakan bahwa pertumbuhan panjang thallus pada rumput laut terlihat lambat pada minggu pertama. Namun, pertumbuhan rumput laut cukup cepat saat umur 6-7 minggu.

Peningkatan pertumbuhan rumput laut tidak terlepas dari penggunaan metode rakit apung yang relatif baik digunakan karena mendapatkan intensitas cahaya yang cukup memadai bagi pertumbuhan rumput laut. Wijayanto (2011) menyatakan bahwa penanaman rumput laut dengan menggunakan metode rakit apung lebih efektif karena pergerakan air yang lebih baik sehingga gerak nutrisi yang dibutuhkan untuk pertumbuhan dan perkembangan lebih baik serta didukung dengan cukupnya intensitas cahaya yang diperoleh untuk pertumbuhan rumput laut. Peningkatan pertumbuhan rumput laut dipengaruhi juga oleh penggunaan jaring atau sering disebut kantong rumput laut yang dapat melindungi rumput laut dari gangguan predator sehingga pertumbuhan rumput laut menjadi optimal. Hal ini sesuai dengan pernyataan Dewi $\&$ Suryaningtyas (2020) yang menyatakan fungsi utama dari penggunaan kantong (jaring) rumput laut yaitu untuk melindungi rumput laut dari serangan predator yang sering memakan thallus rumput laut.

\section{Laju Pertumbuhan Spesifik}

Berdasarkan Gambar 4 laju pertumbuhan spesifik dari rumput laut Eucheuma cottonii berdasarakan perlakuan berat bibit awal yang berbeda dimana perlakuan A (berat awal 50 gr) lebih cepat mengalami pertumbuhannya dibandingkan perlakuan B (berat awal 100 gr) dan perlakuan C (berat awal 150 gr). Perbedaan nilai SGR rumput laut yang didapat pada setiap perlakuan diduga disebabkan karena rumput laut dengan berat bibit 50 gr lebih memiliki banyak ruang untuk tumbuh sehingga kebutuhan nutrisi terbagi secara merata dan kompetisinya dalam memperoleh nutrisi tidak terlalu ketat dibandingkan dengan rumput laut dengan berat bibit 100 gr dan 150 gr. Hal ini sejalan dengan pernyataan Tiwa et al. (2013) yang menyatakan bahwa berat awal rumput laut yang akan dibudidaya dapat berpengaruh terhadap pertumbuhannya, dimana bibit awal yang lebih kecil akan memberikan hasil pertumbuhan yang lebih cepat karena tidak terjadi persaingan antar thallus dalam mendapatkan makanan dan cahaya mmatahari.

Persentase laju pertumbuhan spesifik rumput laut yang diperoleh dalam penelitian ini dikategorikan sangat baik untuk pertumbuhan rumput laut. Hal ini karena nilai SGR yang didapat pada ketiga perlakuan berkisar antara 2,57 $\%$ sampai dengan 4, $92 \%$. Anggadiredja et al. (2008) yang menyebutkan pertumbuhan yang baik untuk rumput laut memiliki nilai persentase laju pertumbuhannya melebihi dari 3\%/hari.

\section{Parameter Kualitas Air}


Pertumbuhan rumput laut Eucheuma cottonii sangat dipengaruhi oleh faktor kualitas lingkungan perairan. Kisaran suhu yang diperoleh dalam pengukuran kualitas air di lokasi budidaya Pantai Pandawa selama 7 minggu masa pemeliharaan berkisar antara $28,7-31{ }^{\circ} \mathrm{C}$. Nilai suhu tersebut merupakan kisaran suhu yang baik bagi pertumbuhan rumput laut. Fikri et al. (2015), menyatakan kisaran suhu perairan yang baik untuk pertumbuhan rumput laut adalah $27-30^{\circ} \mathrm{C}$. Lokasi penanaman rumput laut memiliki suhu yang optimal dan baik bagi pertumbuhan rumput laut.

Hasil pengukuran $\mathrm{pH}$ yang diperoleh di lokasi budidaya Pantai Pandawa selama 7 minggu masa pemeliharaan berkisar antara 6,81-7,64 ppt. pH perairan selama pengamatan relatif stabil dan berada pada kisaran optimum bagi pertumbuhan rumput laut. Sadhori (1989) menyatakan kisaran optimal $\mathrm{pH}$ yang baik bagi pertumbuhan rumput laut Eucheuma cottonii berada pada kisaran 6,89,6 ppt. Pengukuran salinitas yang diperoleh pada lokasi budidaya di Pantai Pandawa selama 7 minggu masa pemeliharaan berkisar antara $30-$ 32 ppt. Menurut Sudradjat, (2015) salinitas yang sesuai untuk pertumbuhan rumput laut Eucheuma cottonii berkisar 28-35 ppt. Oksigen terlarut (DO) di lokasi budidaya Pantai Pandawa selama 7 minggu masa pemeliharaan berkisar antara 5,4$6,5 \mathrm{mg} / \mathrm{l}$. Kondisi ini cukup sesuai untuk budidaya rumput laut Eucheuma cattonii. Kandungan oksigen terlarut baik untuk menunjang kegiatan budidaya rumput laut berkisaran antara $3-8 \mathrm{mg} / \mathrm{l}$ (Ditjenkanbud, 2008).

Kandungan nitrat pada perairan di lokasi budidaya Pantai Pandawa selama 7 minggu masa pemeliharaan berkisar antara 0,19-0,25 mg/l. Konsentrasi tersebut masih dikatakan baik untuk dilakukannya kegiatan budidaya rumput laut. Abdan et al. (2013) menyatakan bahwa kandungan nitrat berkisar 0,0013-0,0056 ppm masih mendukung budidaya rumput laut Eheuceuma cottonii. Kandungan fosfat pada penelitian yang dilakukan di lokasi budidaya Pantai Pandawa berkisar antara 0,052-0,064 mg/l. Nilai tersebut menandakan bahwa perairan Pantai
Pandawa sesuai untuk dijadikan sebagai lokasi budidaya rumput laut. Poncomulyo et al. (2008) menyatakan bahwa kisaran fosfat yang optimal untuk pertumbuhan rumput laut adalah 0,051 $1,00 \mathrm{mg} / \mathrm{l}$.

\section{SIMPULAN}

Berdasarkan hasil penelitian yang dilakukan di Pantai Pandawa pertumbuhan rumput laut dengan perlakuan berat bibit awal yang berbeda yaitu perlakuan A (berat awal 50 gr), perlakuan B (berat awal 100 gr), dan perlakuan C (berat awal 150 gr) menggunakan metode rakit apung modifikasi kantong memberikan hasil yang berbeda nyata terhadap pertumbuhan rumput laut Eucheuma cottonii dimana hasil pertumbuhan terbaik dihasilkan pada perlakuan A (berat awal $50 \mathrm{gr}$ ) dengan nilai SGR yaitu sebesar 4,92\%.

\section{UCAPAN TERIMAKASIH}

Penulis mengucapkan terimakasih kepada Kemendikbud atas Beasiswa Bidikmisi No 258/UN14/KM/2018 sehingga penelitian ini dapat terselesaikan dengan baik. Terimakasih juga penulis ucapkan kepada semua pihak yang telah membantu penelitian ini, mulai dari penyusunan proposal, pelaksanaan penelitian sampai penulisan laporan dan penulis ucapan terimakasih juga kepada kelompok petani rumput laut yang telah membantu penelitian ini.

\section{KEPUSTAKAAN}

Abdan A, Rahman, Ruslaini. 2013. Pengaruh Jarak Tanam Terhadap Pertumbuhan dan Kandungan Karagenan Rumput Laut (Kappahycus alvarezii) Menggunakan Metode Long Line. Jurnal Mina Laut Indonesia, 3(12): 113-123.

Aldoni M. 2011. Laju Pertumbuhan Rumput Laut Eucheuma cottoni dengan Metode Rak Bertingkat di Perairan Kalianda Kabupaten Lampung Selatan. [Skripsi]. Indralaya: Universitas Sriwijaya.

Anggadiredja JT, Zatnika A, Purwato H, Istini S. 2008. Rumput Laut, Pembudidayaan, Pengolahan dan Pemasaran Komoditas 
Perikanan Potensial. Jakarta: Penebar Swadaya.

Ariyanto S. 2005. Survey dan Analisa Rumput Laut (Eucheuma cottoni) PT. Dwijaya Abadi Surya Pratama International.

Damayanti T, Aryawati R, Fauziyah. 2019. Laju Pertumbuhan Rumput Laut Eucheuma cottonii (Kappaphycus alvarezi) Dengan Bobot Bibit Awal Berbeda Menggunakan Metode Rakit Apung Dan Long Line Di Perairan Teluk Hurun, Lampung. Maspari Journal, 11(1): 17-22

Dewi APWK, Ekawaty R. 2019. Potensi Budidaya Rumput Laut dalam Kaitannya dengan Dampak Perkembangan Pariwisata di Perairan Pantai Kutuh, Badung, Bali. Journal of Marine and Aquatic Sciences, 5(1): $94-99$

Dewi APWK, Saraswati SA. 2016. Kajian Pengembangan Usaha Budidaya Rumput Laut Di Pantai Kutuh, Badung, Provinsi Bali. Journal of Marine and Aquatic Sciences. 2(1): $1-5$

Dewi APWK, Suryaningtyas ES. 2020. Pola Pertumbuhan Rumput Laut Yang Menggunakan Kantong Dan Tanpa Kantong Di Perairan Pantai Kutuh, Badung, Bali. Journal of Marine and Aquatic Sciences. 6(1): 147-151

Direktorat Jendral Perikanan Budidaya. 2008. Petunjuk teknis budidaya rumput laut Euchema spp. DKP RI, Ditjenkanbud. Jakarta. $41 \mathrm{hlm}$

Prihastuti D, Abdassah M. 2019. Karagenan dan Aplikasinya di Bidang Farmasetik. Jurnal Majalah Farmasetika. 4(5): 147-155

Fikri M, Rejeki S, Widowati LL. 2015. Produksi dan Kualitas Rumput Laut (Eucheuma cottonii) dengan Kedalaman Berbeda di Perairan Bulu Kabupaten Jepara. Journal of Aquaculture Management and Technology. 4(2): 67-74.

Hamid A. 2009. Pengaruh Berat Bibit awal dengan Metode Apung (Floating method) Terhadap Persentase Pertumbuhan Harian Rumput Laut (Eucheuma cottonii) [Skripsi]. Fakultas Sains dan Teknologi, Universitas Islam Negeri.

Kasim M, Asnani. 2012. Penentuan Musim Reproduksi Generatif dan Preferensi Perekatan Spora Rumput Laut (Eucheuma cottonii). Fakultas Perikanan dan Ilmu
Kelautan, Universitas Haluoleo. Jurnal Ilmu Kelautan 17(4): 209-216

Mako H, Koniyo Y, Muharam A. 2018. Penggunaan Kantong pada Metode Long Line terhadap Pertumbuhan Alga Laut. Jurnal Ilmiah Perikanan dan Kelautan. 6(1): 26-37

Medinawati KD. 2017. Perbandingan Perkembangan Pengelolaan Pantai Pandawa Sebagai Daya Tarik Wisata Di Desa Kutuh, Kecamatan Kuta Selatan, Kabupaten Badung. Jurnal Destinasi Pariwisata. 5(1): 12-16

Tiwa RB, Mondoringin L, Salindeho I. 2013. Pertumbuhan Rumput Laut Kappaphycus alvarezii pada Perbedaan Kedalaman dan Berat Awal di Perairan Talengen Kabupaten Kepulauan Sangihe. Laporan Penelitian. Sulawesi Utara.

Poncomulyo TH, Maryani, L. dan Kristiani. 2008. Budidaya dan Pengolahan Rumput Laut. Agromedia. Jakarta, $14-15$.

Riris CG, Dirgayusa IGNP, Puspitha NIPR. 2019. Perbandingan Laju Pertumbuhan Rumput Laut (Eucheuma cottonii) Dengan Menggunakan Sistem Budidaya Ko-kultur dan Monokultur di Perairan Pantai Geger, Nusa Dua, Bali. Journal of Marine Research Technology, 2 (1): 8-16

Sadhori SN. 1989. Budidaya Rumput Laut. Yogyakarta: Balai Pustaka.

Sudjiharno. 2001. Teknologi Budidaya Rumput Laut. Balai Budidaya Laut. Lampung. 35-46 hlm

Sudradjat A. 2015. Budidaya Komoditas Laut Unggul. Penebar Swadaya. Jakarta.

Wijayanto TH, Muhammad, Riris A. 2011. Studi Pertumbuhan Rumput Laut Eucheuma cottonii dengan Berbagai Metode Penanaman yang berbeda di Perairan Kalianda, Lampung Selatan. Journal Maspari. 3(2): 51-57. 